austenite contents although $\alpha$ brass and rock salt have also been used.

\section{References}

${ }^{1}$ B. L. Averbach and M. Cohen: X-ray Determination of Retained Austenite by Integrated Intensities. Trans. AIME (1948) 176, p. 401; Metals Technology (September 1947).
${ }^{2}$ B. L. Averbach, L. S. Castleman, and M. Cohen: Measurement of Retained Austenite in Carbon Steels. Trans. ASM (1950) 42, p. 112.

${ }^{3}$ K. E. Beu: Modifications of an X-ray Method for the Measurement of Retained Austenite Concentrations in Hardened Steels. Trans. AIME (1952) 194, p. 1327; Journal of Metals (December 1952).

Technical Note

\title{
Regarding Sigma Phase Formation
}

\section{by David S. Bloom and Nicholas J. Grant}

$\mathbf{I}^{\mathrm{N}}$ $\mathrm{N}$ recent reports, Sully ${ }^{1}$ and Beck and coworkers ${ }^{2}$ have advanced hypotheses concerning the formation of the $\sigma$ phase. Both of these hypotheses are based on Pauling's theories of the electronic configuration of the elements of the first transition group. Sully considered that the number of electrons which can be absorbed in filling electron "holes" is the factor which determines whether or not the $\sigma$ structure can form. Beck suggested that the presence of a certain concentration of electron "holes" is the controlling value.

It can be shown that a similar criterion can be developed without making reference to Pauling's theories. Table I shows the elements of the first transition group and the incidence of the $\sigma$ structure in the binary systems of these elements according to the data presently available. Also appended is the number of electrons considered to exist in the $3 d-4 s$ levels of these elements. If the atomic percentages for the $\sigma$ phase are listed as shown in Table II, and if the number of electrons in the $3 d-4 s$ levels per atom is calculated for the $\sigma$ boundary values, the results are as shown in the last column. It can be seen that the numerical values are all in the vicinity of 7 electrons per atom. This is true also for the ternary $\mathrm{Cr}-\mathrm{Mo}-\mathrm{Ni} \sigma$ phase, which occurs in a system in which none of the binary compositions are known to develop the $\sigma$ phase. In the Fe-Mo binary, the high temperature $\sigma$ phase, which occurs at a composition of 50 atomic pct of each element, also yields a value of 7 electrons per atom.

From inspection of Tables I and II, it develops that any series of sequential numbers which is assigned to the elements under consideration will result in the numbers pertaining to $\sigma$ compositions grouping themselves around one specific number. It does not follow, however, that this random number necessarily has physical significance. Such a point has already been discussed by Hume-Rothery. ${ }^{3}$

One interesting point develops from this study, however, and that is the position of manganese with reference to the other elements and to the $\sigma$ phase. In the system used here, the formation of $\sigma$ phase is associated approximately with the value of 7 electrons per atom, which is also the number of electrons per atom that manganese has. Manganese, it will be recalled, exists in three different crystal forms, none of which are the usual, simpler metallic forms; on the other hand, elements just to the left of manganese (in Table I) generally have lower coordination-number structures (body-centered cubic) than do elements to the right of manganese (face-centered

D. S. BLOOM, Student Associate AIME, is Research Assistant, and N. J. GRANT, Member AIME, is Associate Professor, Dept. of Metallurgy, Massachusetts Institute of Technology, Cambridge, Mass.

TN 143E. Manuscript, Oct. 3, 1952.
Table I. Chart Showing Occurrence of the Sigma Phase in Binary Systems of Elements of the First Transition Group

\begin{tabular}{|c|c|c|c|c|c|c|}
\hline & $\mathbf{v}$ & $\mathbf{C r}$ & Mn & $\mathbf{F e}$ & Co & $\mathbf{N i}$ \\
\hline $\mathbf{v}$ & 一 & - & $\sigma$ & $\sigma$ & $\sigma$ & $\sigma$ \\
\hline $\mathrm{Cr}$ & - & - & $\sigma$ & $\sigma$ & $\sigma$ & - \\
\hline Mn & $\sigma$ & $\sigma$ & - & - & - & - \\
\hline $\mathrm{Fe}$ & $\sigma$ & $\sigma$ & $\sigma$ & - & - & - \\
\hline Co & $\sigma$ & $\sigma$ & - & - & - & - \\
\hline $\mathrm{Ni}$ & $\sigma$ & $\overline{6}$ & $\overline{7}$ & $\overline{8}$ & $\overline{0}$ & $\overline{10}$ \\
\hline $\begin{array}{l}\text { No, of electrons } \\
\text { in } 3 d-4 s \text { levels } \\
\text { per atom }\end{array}$ & 5 & 6 & 7 & 8 & 9 & 10 \\
\hline
\end{tabular}

Table II. Electrons/Atom Number for Various Sigma Phases

\begin{tabular}{|c|c|c|}
\hline System & $\begin{array}{l}\text { Boundaries for } \sigma \text { Phase } \\
\text { in Atomic Pct at } \\
\text { Temperatures Indicated }\end{array}$ & $\begin{array}{c}\text { Electrons/Atom } \\
\text { Ratio Corre- } \\
\text { sponding to } \\
\sigma \text { Phase } \\
\text { Boundaries }\end{array}$ \\
\hline $\begin{array}{l}\text { V-Mn } \\
\text { V-Fe } \\
\text { V-Co } \\
\text { V-Ni } \\
\text { Cr-Mn } \\
\text { Cr-Fe } \\
\text { Cr-Co } \\
\text { Mo-Fe } \\
\text { Mo-Co } \\
\text { Cr-Mo-Ni }\end{array}$ & $\begin{array}{l}24.3 \text { pct } \mathrm{V} \\
37-57 \text { pct } \mathrm{V}\left(700^{\circ} \mathrm{C}\right) \\
40-54.9 \text { pct V } \\
55-65 \text { pct V } \\
19-24 \text { pct } \mathrm{Cr}\left(800^{\circ} \mathrm{C}\right) \\
43.5-49 \text { pct } \mathrm{Cr}\left(600^{\circ} \mathrm{C}\right) \\
56.6-61 \text { pct } \mathrm{Cr} \\
47-50 \text { pct } \mathrm{Mo}\left(1400^{\circ} \mathrm{C}\right) \\
59-61 \text { pct Mo }\left(1500^{\circ} \mathrm{C}\right) \\
37 \mathrm{Cr}, 27 \mathrm{Mo}, 36 \mathrm{Ni}, \\
42 \mathrm{Cr}, 32 \mathrm{Mo}, 26 \mathrm{Ni}\left(1250^{\circ} \mathrm{C}\right)\end{array}$ & \begin{tabular}{l}
\multicolumn{1}{c}{6.5} \\
$7.3-6.9$ \\
$7.4-6.8$ \\
$7.2-6.7$ \\
$6.84-6.78$ \\
$7.1-7.0$ \\
$7.3-7.2$ \\
$7.1-7.0$ \\
$7.23-7.17$ \\
$7.4-7.0$
\end{tabular} \\
\hline
\end{tabular}

cubic). The contribution to a complex crystal structure by the interalloying of elements from opposite sides of manganese is significant in that the $\sigma$ phase is formed in binary systems including one element from each side of manganese, with manganese capable of participating with both sides.

It is indeed an interesting coincidence that manganese, with 7 electrons per atom, solidifies in complex crystal forms, and that when alloys of the transition elements are made which have seven $3 d-4 s$ electrons per atom, they, too, tend to assume a complex crystal form.

From the above, it might be deduced that the study of the $\sigma$ phase might be advanced by a critical examination of the element manganese and how its structure is affected by small additions of elements which change the $3 d-4 s$ electrons per atom number. The role of atom size would also be of interest in $\sigma$ formation.

\section{References}

${ }^{1}$ A. H. Sully: The Sigma Phase in Binary Alloys of the Transition Elements. Journal Inst. Metals (1951) 80, Part 4, p. 173.

${ }^{2}$ S. Rideout, W. D. Manly, E. L. Kamen, B. S. Lement, and P. A. Beck: Intermediate Phases in Ternary Alloy Systems of Transition Elements. Trans. AIME (1951) 191, p. 872; Journal OF Metals (October 1951).

${ }^{8} \mathrm{~W}$. Hume-Rothery, H. M. Irving, and R. J. P. Williams: The Valencies of the Transition Elements in the Metallic State. Proc. Royal Soc. (September 1951) 208A, p. 431. 